\title{
Recent progress in Quaternary geology of Brazil
}

\author{
Instituto de Geociências, Universidade de São Paulo, São Paulo, Brazil.
}

\begin{abstract}
Until very recently, papers dealing with Quaternary geology were very scarce in the Brazilian geoscientific literature. In spite of its multidisciplinary nature, the only existing publications on this subject were related to geotechnical and/or geomorphical characteristics. In the last 30 years, this picture changed due to several international programs such as the IGCP projects and agreements between ORSTOM (France) and CNPq (Brazil). They have started with studies of relative sealevel changes along northeastern, central, and southeastern coasts, conducted together with 700 radiocarbon dates. These researches have been followed by paleoclimatic studies, mostly done by palynological and stable carbon isotopes analyses, mainly in Amazon, central-western and southern areas. Finally, several neotectonic studies are in progress, especially in Amazon and southeastern regions. Those studies resulted in a better knowledge about the Quaternary evolutionary history of Brazil, mostly during the Late Pleistocene and Holocene. More of those studies have to be developed in order to adequately subsidize the sustainable development of this country.
\end{abstract}

\section{Introduction}

Quaternary geology deals with the ultimate chapter of Earth's history, covering the last $1.81 \mathrm{Ma}$ (Van Couvering, 1997). The majority of the geologic processes existing during this short time interval are still active nowadays and will continue during the next million years. Therefore, the study of those processes is fundamental for environmental geology, which is commonly considered as synonymous with applied geology (Keller, 1988).

Moreover, building materials like sands and gravels are provided by Quaternary unconsolidated deposits; and because of their voluminous consumption, they can be considered the most important mineral resource for modern civilization (Lüttig, 1979).

Quaternary sediments are also important due to the following additional reasons:

a) About $70 \%$ of the human population live on coastal plains and floodplains, originated respectively by marine and fluvial processes.

b) The great majority of civil engineering works (building, bridge, highway, harbor, etc.) are located on Quaternary unconsolidated sediments. Consequently, a better knowledge of those sediments is essential for a suitable evaluation of soil mechanics data.

c) Farming and forestry activities are essentially developed over Quaternary sediments and soils. Therefore, Quaternary geology becomes very important for pedological researches. d) Frequently Quaternary deposits constitute important aquifers, providing abundant groundwater for industrial and domestic uses.

Although the observations presented above are well known, Quaternary geology remained practically ignored by a great majority of Brazilian geologists during a long time. Meanwhile in the Northern Hemisphere, Quaternary geological studies began with Penck and Brückner (1909), dealing with Alpine glacial landscapes. In Brazil, these researches were intensified only about 30 years ago, notwithstanding the pioneer geomorphological works done mostly by A.N. Ab'Saber and J.J. Bigarella.

Intensification of Quaternary geological studies coincided with the creation in 1971 of the "Quaternary Technical-Scientifical Commission" within the SBG (Brazilian Geological Society). Four special symposia on the Brazilian Quaternary studies have been organized by this commission, which was replaced in 1984 by the ABEQUA (Brazilian Association of Quaternary Studies). As a society affiliated to SBG, ABEQUA is holding its 7th Congress in October 1999 at Porto Seguro (State of Bahia).

In accordance with the inter- and multidisciplinary peculiarities of the Quaternary geology, some of the most important themes developed in recent years in Brazil are as follows:

a) Quaternary relative sea-level changes,

b) Quaternary climatic fluctuations,

c) Neotectonics and Quaternary tectonics.

\section{Quaternary relative sea-level changes}

Although Darwin (1841) first recognized the beachrocks present along the State of Pernambuco coast as evidence of Holocene sealevel change, these studies were very scarce until the seventies (Tessler and Mahiques, 1996).

The first studies using radiocarbon ages were done by Laborel and his colleagues (Van Andel and Laborel, 1964; Delibrias and Laborel, 1971). The REMAC (Global Reconnaissance of the Brazilian Continental Margin), a joint project involving many universities and governmental agencies, probably brought about the most significant progress in this subject (Kowsmann et al., 1977; Corrêa, 1987).

Since 1974, many studies have been done on the central and southern Brazilian coastal plains, which improved the relative sealevel change history in these regions, mostly for the last 7,000 years (Suguio et al., 1985; Villwock et al., 1986; Villwock and Tomazelli, 1995; Martin et al., 1996).

\section{Evidence of relative sea-levels below the present}

The continental margin between Torres and Chuí (State of Rio Grande do Sul) is best studied and supplied with many ancient sealevels situated between 20-26 m, 32-45 m, 60-70 m, 100-110 m, and 120-130 m (Corrêa and Toldo Júnior, 1996). They are represented by ancient shorelines, originated during relative sea-level still-stand episodes. 
Based on the eustatic curve delineated by Corrêa (1990), the paleogeographic evolution of the continental shelf along the State of Rio Grande do Sul coast can be subdivided into three phases :

a) First phase - 17,500 to 16,000 years BP. About 17,500 years BP, when relative sea-level was at least $130 \mathrm{~m}$ below the present one, practically all the continental shelf was emerged and submitted to an intensive erosion. The relative sea-level rose very rapidly (about $2 \mathrm{~cm} /$ year), being stabilized about 16,000 years ago. The ancient shoreline of this phase is represented by fine sand on the inner shelf, intercalated by medium sand, probably supplied by the coastal drainage net.

b) Second phase - 16,000 to 11,000 years BP. The relative sea-level rise during this phase was diminished to about $0.6 \mathrm{~cm} /$ year. This transgressive episode is recorded on the middle and outer continental shelves. Based on microorganisms, the relative sea-level between 60-70 $\mathrm{m}$ indicated the beginning of the Holocene when a climatic amelioration was verified.

c) Third phase - 11,000 to 6500 years BP. During this episode the relative sea-level rise was speeded up to about $1.6 \mathrm{~cm} /$ year, with two still-stand episodes between $32-45 \mathrm{~m}$ and 20-25 m. Meanwhile a transgressive process was active and the shoreline was shifting westwardly. During this phase, fine sediments covered the transgressive sands situated on middle and outer continental shelves. The still-stand episodes are represented by biodetrital gravel and heavy mineral-rich layers, which are indicative of ancient shorelines.

\section{Evidence of relative sea-levels above the present}

They have been better studied between the States of Santa Catarina and Bahia, where about 700 radiocarbon ages were obtained by Suguio and his colleagues (Suguio et al., 1985; Martin et al., 1996). These results are also valid for the State of Rio Grande do Sul.

The evidence of these relative sea-levels, including the upper Pleistocene sea-levels, is represented by geological (wave-built and wave-cut terraces, as well as beachrocks), biological (vermetid incrustations, coral reef buildups, and Callichirus burrows) and prehistorical (shell-middens) records.

According to these studies, at least four phases of relative sealevels higher than the present one have been recognized during the Quaternary:

a) Relative sea-levels before 123,000 years BP. They are represented by two ancient barrier island-lagoonal systems, situated at about 20-25 m (Barrier I) and $15 \mathrm{~m}$ (Barrier II). They have been tentatively dated as 400,000 years BP and 325,000 years BP and are attributed respectively to oxygen isotope stages 11 and 9 .

Barrier I is represented only in the State of Rio Grande do Sul coastal plain; there are vestiges of Barrier-II terrace between states of Santa Catarina and southern São Paulo.

b) Relative sea-levels of about 123,000 years BP. This episode is recorded by wave-built terraces situated at about $8 \pm 2 \mathrm{~m}$, continuous from the states of Rio Grande do Sul to Paraíba.

Five Io/U ages were obtained from coral (Siderastrea) samples (Bernat et al., 1983) collected from the basal portion of the terrace in the State of Bahia. The average age of those sediments is 123,500 \pm 5,700 years BP. This episode could be correlated with the Sangamon (North America) or Eemian (Scandinavia) transgression previously recognized by Bloom et al. (1974). It corresponds to Barrier III of the State of Rio Grande do Sul (Villwock et al., 1986), and is tentatively attributed to the oxygen isotope stage 5 .

c) Holocene relative sea-levels higher than the present. The last 6500 years after the third phase of the transgressive episode (Corrêa, 1990), recognized on the State of Rio Grande do Sul continental shelf, was studied in detail. This episode is internationally known as Flandrian or Postglacial Transgression, but according to the difference in feature from the curves obtained for the majority of the Northern Hemisphere countries, it is called more adequately the Santos Transgression in Brazil.

\section{Geological evolution of the Brazilian coastal plains}

Based on Quaternary relative sea-level changes it was possible to establish a general evolutionary model, useful in the sector of the Brazilian coast between Macaé (northern State of Rio de Janeiro) and Recife (State of Pernambuco). This coastline stretches about 3,000 $\mathrm{km}$, being characterized by the presence of Tertiary Barreiras Formation, situated between the rearguard Precambrian crystalline rock mountains and the Quaternary coastal plains (Martin et al., 1987). On the other hand, along the southern part of State of São Paulo and the states of Paraná and Santa Catarina coasts, this model is partially useful for local reasons (Martin, Suguio, and Flexor, 1987a).

The complete evolutionary model with four barrier island lagoonal systems were recognized only in the State of Rio Grande do Sul coast (Villwock and Tomazelli, 1996).

Geological evolution of Quaternary coastal plains situated at the mouths of the most important rivers, which was preliminarily studied by Bacoccoli (1971), is presently well-known thanks to the innumerous papers published (Martin et al., 1993).

\section{Quaternary climatic fluctuations}

Starting in the fifties, several papers emphasizing strong discrepancies between the present faunistic, floristic and geomorphological distributions and the climates, have been published (Ab'Saber, 1957; Tricart, 1958; Haffer, 1969; Bigarella et al., 1975 and Vanzolini, 1992). Among several paleoclimatic indicators, frequently known as proxy records, palynological analyses, accompanied by radiocarbon ages, have been done in Brazil. Also charcoals present in soils, lacustrine and paludal deposits or in eolian dune sands have been frequently used as paleoclimatic indicators (Soubies et al., 1980; Barreto et al., 1996; Turcq et al., 1998). Commonly, there is doubt if the charcoals have a natural or an artificial origin (anthropogene), but in any case they represent a record of drier and warmer climates.

In a virtual absence of palynological or even of charcoal records, like in ferralitic soils of equatorial and tropical areas, ${ }^{13} \mathrm{C} /{ }^{12} \mathrm{C}$ ratios of soil organic matters can be used to obtain information of previous existing vegetation communities. According to Troughton et al. (1974) this parameter could indicate the presence of $\mathrm{C}_{3}$ (arboreal) or $\mathrm{C}_{4}$ (non-arboreal) plants, as well as their relative proportions in net biomass primary productivity of the past.

\section{Some examples of Quaternary paleoclimatic studies}

One of the best examples of paleoclimatic study, using mostly palynological data and radiocarbon ages, was done in Serra dos Carajás (State of Pará). Palynological data obtained from 50 samples collected from a $6.50 \mathrm{~m}$-long lacustrine sediment core allowed the establishment of eight palynological zones. Absy et al. (1991) recognized, in this study of the Amazon area, the existence of:

a) Rainforest retraction periods. The obtained palynological spectra indicated that about $60,000,40,000$, and 23,000 to 11,000 years 
$\mathrm{BP}$, a rainforest retraction occurred, when the climate was drier than presently in the area.

b) Rainforest expansion periods. High frequencies of pollen of arboreal plants, especially between 9,500 and 8,000 years BP, are indicative of a wetter paleoclimate than the present in this area.

Other studies using mineral components (quartz, kaolinite, siderite, and amorphous silica), $\mathrm{C} / \mathrm{N}$ and ${ }^{13} \mathrm{C} /{ }^{12} \mathrm{C}$ ratios, according to Sifeddine et al. (1994), ratified the previous palynological studies.

Many other palynological studies were performed in several sites in Brazil, mostly after 1980, including areas presently dominated by savanna vegetation (Central Brazil), by Araucaria forest (Southern Brazil), and by "caatinga" (Northeastern Brazil).

In spite of many paleoclimatic studies done throughout Brazil, using palynological, isotopical, and mineralogical analyses, the correlation of these data is not a simple task, mostly due to their diachronicities. However, it is encouraging that some Quaternary worldwide paleoclimatic changes, like hypsithermal age (about $9,000-2,500$ years BP), neoglaciation (about 2,500-1,000 years BP), and the little ice age (1,450 to $1,890 \mathrm{AD})$, are apparently recognizable in the Brazilian paleoclimatic records.

\section{Neotectonics and Quaternary tectonics}

The pioneer works on neotectonics in Brazil appeared about 50 years ago (Sternberg, 1950; Freitas, 1951). However, only 20 years later Brazilian geologists got interested in this subject, mainly due to huge civil engineering works like hydroelectrical and thermonuclear projects, and harbor constructions. Probably the best known regions of Brazil regarding neotectonics are the Amazon area (Costa et al., 1996) and the Southeastern Brazil (Riccomini, 1989).

As demonstrated by Suguio and Martin (1996), there is no doubt that neotectonics played a very important role in geological evolution of Brazilian coastline. Unfortunately there are only a few places where tectonic movements have been dated (Martin et al., 1986).

\section{References}

Ab'Saber, A.N., 1957. Conhecimentos sobre as flutuações climáticas do Quaternário no Brasil. Boletim da Sociedade Brasileira de Geologia, 6:3948

Absy, M.L., Cleef, A., Fournier, M., Martin, L., Sifeddine, A., Ferreira da Silva, M., Soubies, F., Suguio, K., Turcq, B., Van der Hammen, T.,1991. Mise en évidence de quatre phases d'ouverture de la forêt dense dans sudest de I'Amazonie au cours des 60.000 dernières années. Prémière comparaison avec d'autres regions tropicales. Comptes Rendus de 1'Académie de, Sciences de Paris, Tome 312:673-678.

Bacoccoli, G., 1971. Os deltas marinhos holocêndnicos brasileiros. Uma tentativa de classificação. Boletim Técnico da Petrobras, 14:5-38

Barreto, A.M.F., Pessenda, L.C.R., Suguio, K., 1996. Probable drier climate evidenced by charcoal bearing middle São Francisco river paleodunes, State of Bahia, Brazil. Anais da Academia Brasileira de Ciências, 68 (suplemento):43-48.

Bernat, M., Martin, L., Bittencourt, A.C.S.P., Vilas-Boas, G.S., 1983. Datation Io/U du plus haut niveau marin du dernier interglaciaire sur le côte du Brésil. Utilisation du ${ }^{229} \mathrm{Th}$ comme traceur. Comptes Rendus de l'Académie de Sciences de Paris, Tome 296:197-200.

Bigarella, J.J., Andrade-Lima, D., Riehs, P.J., 1975. Considerações a respeito das mudanças paleoambientais na distribuição de algumas espécies vegetais e animais no Brasil. Anais da Academia Brasileira de Ciências, 47 (suplemento): 411-464.

Bloom, A.L., Broecker, W.S., Chappell, J., Matthews, R.K., Mesolella, K. J., 1974 Quaternary sea-level fluctuations on a tectonic coast: New ${ }^{238} \mathrm{Th} /{ }^{234} \mathrm{U}$ dates from the Huon Peninsula, New Guinea. Quaternary Research, 4:185-205.

Corrêa, I.C.S., 1987. Evidences of sea level fluctuations in the Rio Grande do Sul continental shelf, Brazil. Quaternary of South America and Antarctic Peninsula, 4:237-247.
Corrêa, I.C.S, 1990. Analyse morphostructurale et évolution paléogeographique de la plate-forme continentale Atlantique Sud Brésilienne (Rio Grande do Sul, Brésil) Thèse de doctorat, Université de Bordeaux I, 314 pp.

Corrêa, I.C.S. and Toldo Júnior, E.E., 1996. The sea-level stabilization in the Rio Grande do Sul continental shelf, Brazil. Anais da Academia Brasileira de Ciências, 70:213-219.

Costa, J.B.S., Bemerguy, R.L., Hasui, Y., Borges, M.S., Ferreira Júnior, C.R.P., Bezerra, P.E.L., Fernandes, J.M.G., Costa, M.L., 1996. Neotectônica da região amazônica: aspectos estruturais, tectônicos, geomorfológicos e estratigráficos. Geonomos, 4:23-44.

Darwin, C.H., 1841. On a remarkable bar of sandstone of Pernambuco on the coast of Brazil. Dublin Philosophy Magazine and Journal of Science, 19:257-261.

Delibrias, G. and Laborel, J. 1971. Recent variations of sea-level along the Brazilian coast. Quaternaria, 10:45-49.

Freitas, R.O., 1951. Ensaio sobre a tectônica moderna do Brasil. Boletim da Faculdade de Filosofia, Ciências e Letras, USP, 130:1-120.

Haffer, J., 1969. Speciation in Amazonian forest birds. Science, 165:131-137.

Keller, E.A., 1988. Environmental geology. Charles E. Merrill Publ. Co.: Columbus (Ohio), 548 pp. (5th.edition).

Kowsmann, R.O., Costa, M.P.A., Vicalvi, M.A., Coutinho, M.G.N., Gamboa, L.A.P., 1977. Modelo de sedimentação holocênica na plataforma continental sul-brasileira. In: Projeto REMAC - Evolução sedimentar holocênica da plataforma continental e do talude do sul do Brasil. Petrobras/CENPES, 2:7-26 (Série Projeto REMAC)

Lüttig, G.W., 1979. Geoscientific maps as a basis for land-use planning. Geol. Fören. Stockh. Förh. 101:65-69.

Martin, L., Flexor, J.M., Bittencourt, A.C.S.P., Dominguez, J.M.L.,1986. Neotectonic movements on a passive continental margin, Salvador region, Brazil. Neotectonics, 1:87-103.

Martin, L., Suguio, K., Flexor, J.M., Dominguez, J.M.L., Bittencourt, A. C.S.P., 1987a. Quaternary evolution of the central part of the Brazilian coast. The role of relative sea-level variation and of shoreline drift. In: UNESCO Reports in Marine Science: Quaternary coastal geology of West Africa and South America, 43:97-145.

Martin, L., Suguio, K., Flexor, J.M., 1987b. Relative sea-level reconstruction during the last 7,000 years along the States of Paraná and Santa Catarina: Additional information derived from shell-middens. Quaternary of South America and Antarctic Peninsula, 4:219-236.

Martin, L., Suguio, K., Flexor, J.M., 1993. As flutuações do nível do mar durante o Quaternário superior e a evolução geológica dos "deltas" brasileiros. Boletim IG-USP, Publicação Especial, 15:1-186.

Martin, L., Suguio, K., Flexor, J.M., Dominguez, J.M.L., Bittencourt, A. C.S.P., 1996. Quaternary sea-level history and variation in dynamics along the central Brazilian coast: Consequences on coastal plain construction. Anais da Academia Brasileira de Ciências, 68:303-354.

Penck, A. and Brückner, E., 1909. Die Alpen im Eiszeitalter.Tauchnitz: Leipzig, 1199 pp.

Riccomini, C., 1989. O Rift Continental do Sudeste do Brasil. Instituto de Geociências, USP. Tese de doutoramento, $256 \mathrm{pp}$.

Sifeddine, A, Bertrand, P., Fournier, M., Martin, L., Servant, M., Soubies, F., Suguio, K., Turcq, B., 1994. La sedimentation organique lacustre en milieu tropical humide (Carajás, Amazonie orientate, Brésil): Rélation aves les changements climatiques au cours de 60.000 dernières années. Bulletin de la Société Géologique de France, 165:613-621

Soubies, F., 1980. Existence d'une phase séche en Amazonie brésilienne datée par la présence de charbons dans les sols (6.000-3.000 ans BP). Cahiers ORSTOM Série Géologie, 11:133-148.

Sternberg, H.O.R., 1950. Vales tectônicos na planície amazônica? Revista Brasileira de Geografia, 12:3-26.

Suguio, K. and Martin, L.1996. The role of neotectonics in the evolution of the Brazilian coast. Geonomos, 4:45-53.

Suguio, K., Martin, L., Bittencourt, A.C.S.P., Dominguez, J.M.L., Flexor, J.M, 1985. Flutuações do nível relativo do mar durante o Quaternário superior ao longo do litoral brasileiro e suas implicações na sedimentação costeira. Revista Brasileira de Geociências, 15:273-286.

Tessler, M.G. and Mahiques, M.M.(orgs.), 1996. Levantamento bibliográfico sobre a Geologia Marinha no Brasil (1841-1992). Programa de Geologia e Geofísica Marinha (PGGM), 320 pp.

Tricart, J., 1958. Division morphoclimatique du Brésil Atlantique Central. Révue de Géomorphologie Dynamique, 9:1-12.

Troughton, J.H., Stout, J.D., Rafter, T., 1974. Long term stability of plant communities. Carnegie Institute of Washington Yearbook, 73:838-845.

Turcq, B., Sifeddine, A., Martin, L., Absy, M.L., Soubies, F., Suguio, K., Volkmer-Ribeiro, C., 1998. Amazonia rainforest fires: A lacustrine record of 7,000 years. Ambio, 27:139-142. 
Van Andel, T.H. and Laborel, J., 1964. Recent high sea-level stands near Recife, Brazil. Science. 145:580-581.

Van Couvering, J.A., 1997. Preface: the new Pleistocene. in: J.A. Van Couvering (ed.) The Pleistocene boundary and the beginning of the Quaternary. World and Regional Geology 9. Cambridge University Press: 296 pp. Vanzolini, P.E., 1992. Paleoclimas e especiação em animais da América do Sul. In: Amazônia: tempos e espaços. Revista Estudos Avançados, 15:41-65.

Villwock, J.A. and Tomazelli, L.J., 1995. Geologia costeira do Rio Grande do Sul. Notas Técnicas (CECO/UFRGS), 8:1-45.

Villwock, J.A, Tomazelli, L.J., Loss, E.L., Dehnhardt, E.A., Horn Filho, N.O., Bachi, F.A., Dehnhardt, B.A., 1986. Geology of the Rio Grande do Sul coastal province. Quaternary of South America and Antarctic Peninsula, 4:79-97.
Dr. Kenitiro Suguio is professor of geology (retired) at the University of São Paulo (State of São Paulo), where he remains as a lecturer and advisor of the graduate course on Sedimentary Geology. During the last 25 years he was an active participant of several IGCP and IGBP projects on the Quaternary Geology. He received the Jabuti Prize - 1993 (Câmara Brasileira do Livro) and the commend "Ordem Nacional de Mérito Científico" in 1998.

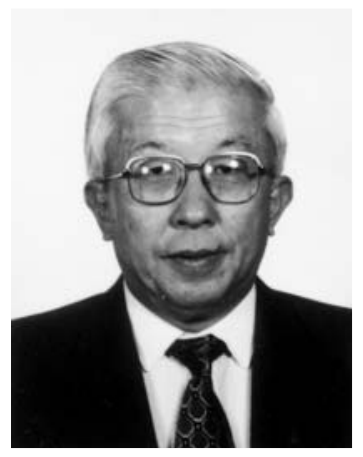

Episodes is your window to the world. Subscribe today! Episodes

\section{Subscription Order}

Name (please print)

Address

City State/Prov.

Country Zip/Postal Code

Please begin my subscription:

$\begin{array}{llll}\text { March } & \text { June } & \text { Sept. } & \text { Dec. } \\ \text { Year } & \text { Year } & \text { Year } & \text { Y Year }\end{array}$

To start your subscription, fill in this form and mail to:

\section{Episodes}

P.O. Box 823

26 Baiwanzhuang Rd.,

Beijing 100037, China

Tel: +86-10-6832 0827; +86-10-6832 7772

Fax: +86-10-6832 8928

E-mail:episodes@public2.bta.net.cn
Payment may be made by:

- Checks (US \$ only) made payable to Episodes

- $\square$ Diners $\square$ JCB $\square$ Visa $\square$ American Express $\square$ Mastercard

Please quote account number, expiry date and signature.

Account\#

Expiry date

Signature

Annual subscription rates: US\$24 